\title{
JENIS DAN RAGAM KERUSAKAN SALURAN PRIMER DAERAH IRIGASI BANDAR LAWEH KABUPATEN SOLOK
}

\author{
Februarman $^{1}$
}

\begin{abstract}
ABSTRAK
Untuk mengalirkan air dari sumbernya (intake) ke areal persawahan diperlukan saluran irigasi. Saluran irigasi akan melewati medan dengan berbagai kondisi topografi. Untuk dapat mengairi areal seluas mungkin, maka saluran primer dipilih sebagai saluran yang mengikuti garis kontur yang disebut juga saluran garis tinggi.

Saluran primer pada Daerah Irigasi Bandar Laweh Kabupaten Solok melintasi medan dengan topografi yang curam, menyebabkan banyaknya kerusakan sepanjang saluran, mulai dari kebocoran saluran, kerusakan tanggul, sampai kelongsoran badan saluran, sehingga suplai air untuk areal persawahan tidak terpenuhi sesuai kebutuhan.

Usaha rehabilitasi yang dilakukan selama ini hanya bersifat parsial, sehingga masalah utama yaitu kekurangan suplai air tidak dapat ditanggulangi. Diperlukan penataan dan perencanaan ulang sistem jaringan irigasi Bandar Laweh, agar daerah sasaran irigasi dapat terairi dengan baik.
\end{abstract}

Kata Kunci : irigasi, saluran garis tinggi, kebocoran, kelongsoran.

\section{PENDAHULUAN}

\subsection{Latar Belakang}

Daerah irigasi yang ada di Kabupaten Solok sebagian sudah merupakan irigasi teknis dan sebagian lainnya masih berupa irigasi sederhana. Sebagian dari jaringan irigasi teknis tersebut ada yang telah rusak, terutama saluran tipe garis tinggi, yaitu saluran yang trasenya mengikuti kontur.

Daerah Irigasi Bandar Laweh dengan luas areal $2860 \mathrm{Ha}$, sumber airnya dari Batang Laweh Sirukam di Kecamatan Payung Sekaki Kabupaten Solok mengairi areal sawah masyarakat yang membentang mulai dari Kenagarian Sirukam, Supayang, Bukik Tandang, Panyakalan, Gaung, Saok Laweh sampai ke kota Solok adalah daerah irigasi yang cukup potensial. Jaringan irigasi ini dibangun tahun 1978, merupakan jaringan irigasi semi teknis dengan kondisi jaringan masih tergolong sederhana.

Trase saluran sekunder dari intake kanan dengan panjang $\pm 10 \mathrm{~km}$ telah mengalami rusak berat sepanjang alirannya. Saluran primer kanan ini mengairi areal pertanian seluas 648 ha membentang mulai dari Sirukam sampai ke Supayang. Saat ini sepanjang $\pm 4 \mathrm{~km}$ ruas saluran mengalami rusak berat, sehingga air untuk kebutuhan irigasi tidak mengalir sampai ke Supayang, karena air hilang akibat bocoran sepanjang trase saluran. Air hanya mampu mengalir sepanjang $\pm 2 \mathrm{~km}$ dari intake.

Trase saluran primer dari intek kiri dengan panjang $\pm 25 \mathrm{~km}$ juga telah mengalami rusak berat sepanjang alirannya. Saluran sekunder kiri ini mengairi areal pertanian seluas 1048 ha membentang mulai dari Sirukam, Tabek, Bukit Tandang, Panyakalan, Gaung, Saok Laweh sampai ke kota Solok.

\footnotetext{
${ }^{1}$ Staf Pengajar Jurusan Teknik Sipil Fakultas Teknik Universitas Andalas
} 
Khusus trase saluran ruas kiri ini, pada kondisi normal mampu mengalirkan air sebesar 1,00 $\mathrm{m}^{3} /$ detik. Pada musim kemarau debit aliran di intake hanya berkisar $0,70 \mathrm{~m}^{3} /$ detik. Kebutuhan air minimum agar seluruh areal yang membentang sampai ke Solok dapat terairi adalah sebesar 1,35 $\mathrm{m}^{3} /$ detik.

Masalah kekurangan pasokan air irigasi terutama untuk areal persawahan yang membentang mulai dari Bukit Tandang, Panyakalan, Gaung, Saok Laweh sampai ke kota Solok telah dikeluhkan masyarakat cukup lama. Mayoritas penduduk di sepanjang kawasan ini mempunyai mata pencaharian sebagai petani.

\subsection{Permasalahan}

Pokok pokok permasalahan adalah :

1. Perbaikan saluran primer yang berulang-ulang, sehingga membutuhkan pembiayaan yang besar dan gangguan terhadap suplai air bagi petak sawah.

2. Berpindah-pindahnya kerusakan sepanjang ruas saluran.

3. Meningkatnya skala kerusakan pada ruas saluran, meliputi longsor pada tebing saluran dan longsor pada tanggul saluran itu sendiri.

Oleh sebab itu, maka perlu diupayakan rehabilitasi dan penyempurnaan jaringan irigasi tersebut, agar trase salurannya dapat berfungsi kembali sebagaimana mestinya, sehingga kebutuhan petani terhadap air irigasi dapat dipenuhi sepanjang waktu. Diperlukan kajian terhadap jenis dan skala kerusakan yang terjadi, serta metode penanggulangannya, agar perencanaan rehabilitasi tepat fungsi dan efektif.

\subsection{Tujuan dan Manfaat Penelitian}

Tujuan dari penelitian adalah :

1. Menentukan penyebab utama dari kerusakan saluran primer yang merupakan saluran garis tinggi.

2. Menentukan alternatif tipe saluran dan usaha penanggulangan kerusakan saluran.

Manfaat dari penelitian adalah :

1. Dapat diketahui faktor-faktor penyebab kerusakan.

2. Sebagai dasar untuk pengambilan keputusan.

3. Pekerjaan rehabilitasi dilakukan setelah adanya kajian dan studi terhadap permasalahan kerusakan saluran, sehingga perencanaan pekerjaan rehabilitasi tidak salah arah.

\section{METODOLOGI PENELITIAN}

Penelitian ini merupakan studi kasus lapangan tentang jenis dan bentuk kerusakan saluran primer pada sistem Irigasi Batang Laweh Kabupaten Solok. Adapun langkah dan pendekatan yang dilakukan adalah sebagai berikut :

\subsection{Pengumpulan Data dan Tinjauan Lapangan}

Data yang dikumpulkan di lapangan meliputi :

1. Data geografis, demografis, topografis serta situasi daerah studi.

2. Data ekonomi dan mata pencaharian penduduk, serta luas lahan pertanian.

3. Dokumentasi lapangan, khususnya daerah irigasi dan saluran primer Irigasi Bandar Laweh, mulai dari bagian hulu (intake) sampai pada lokasi-lokasi kerusakan sepanjang saluran. 


\subsection{Penentuan Jenis dan Bentuk Kerusakan pada Saluran}

Akan dikelompokkan bentuk dan skala kerusakan yang terdapat sepanjang saluran primer. Mulai dari kerusakan kecil, menengah, sampai yang berskala besar serta pemicu kerusakan baru akibat kondisi trase saluran yang ada. Disini juga akan dikaji pengaruh drainase lahan terhadap kerusakan saluran.

\subsection{Pembahasan dan Diskusi}

Setelah mengetahi berbagai bentuk dan jenis kerusakan yang terdapat sepanjang saluran, akan dibahas secara rinci berbagai upaya yang dapat dilakukan dalam hal rehabilitasi saluran serta berbagai alternatif pemecahan masasalah yang dapat dilakukan sehubungan dengan semakin besarnya biaya pemeliharaan dan perawatan saluran. Pertimbangan teknik dan ekonomis juga didiskusikan, karena dengan teknik tertentu perbaikan saluran bisa saja tidak layak secara ekonomis.

\subsection{Pengambilan Kesimpulan dan Rekomendasi}

Hasil dari pembahasan dan diskusi disimpulkan dan akan diberikan saran-saran untuk tindak lanjutnya.

\section{HASIL STUDI DAN PEMBAHASAN}

\subsection{Geografis Kawasan Studi}

Kawasan studi yang berada di Kabupaten Solok tepatnya di Kecamatan Bukit Sundi. Kabupaten Solok dengan luas wilayah $373800 \mathrm{Ha}$ (setelah dimekarkan) dengan letak geografis antara $01^{\circ} 20^{\prime}$ $27^{\prime \prime}$ dan $01^{\circ} 21^{\prime} 39^{\prime \prime}$ Lintang Selatan dan $100^{\circ} 25^{\prime} 00^{\prime \prime}$ dan $100^{\circ} 33^{\prime} 43^{\prime \prime}$ Bujur Timur. Topografi daerah sangat bervariasi dengan ketinggian antara +329 meter sampai +1458 . Disamping mempunyai banyak sungai, kabupaten ini mempunyai danau, yaitu Danau Singkarak, Danau Diatas, Danau Dibawah dan Danau Talang. Batas-batas Kabupaten :

- Sebelah Barat : Kota Padang dan Kabupaten Pesisir Selatan

- Sebelah Utara : Kabupaten Tanah Datar

- Sebelah Timur : Kabupaten Sawah Lunto/ Sijunjung

- Sebelah Selatan : Kabupaten Solok Selatan

Dilihat dari komposisi penggunaan lahan, sebagian besar wilayahnya terdiri dari hutan, baik Hutan Negara maupun Hutan Rakyat.

\section{Tabel 1. Komposisi Penggunaan Lahan Kabupaten Solok}

\begin{tabular}{|l|c|c|}
\hline \multicolumn{1}{|c|}{ Jenis Lahan } & Luas (Ha) & \% luas \\
\hline Hutan Negara & 169.705 & 45,40 \\
Hutan Rakyat & 39.623 & 10,60 \\
Ladang/ Kebun Rakyat & 31.175 & 8,34 \\
Ladang/ Kebun Perusahaan & 25.194 & 6,74 \\
Sawah & 17.569 & 4,70 \\
\hline
\end{tabular}

(Sumber : BPS Kabupaten Solok 2008)

Luas lahan sawah 17.569 Ha merupakan areal sawah terluas di Sumatera Barat. Disamping sebagai lumbung beras Sumatera Barat, dengan jumlah sungai 26 buah, danau 4 buah dan gunung 1 buah, maka kabupaten ini juga mempunyai potensi yang cukup besar untuk daerah wisata. 


\subsection{Sosial Ekonomi}

Sebagian besar sumber penghidupan masyarakat di Kabupaten Solok adalah bekerja di bidang pertanian $(73 \%)$, sedangkan sisanya bekerja di bidang indsutri, pertambangan dan penggalian, listrik, gas dan air, konstruksi, perdagangan, transportasi dan keuangan. Karena sebagian besar penduduk berusaha di bidang pertanian, maka pengembangan areal pertanian harus mendapat perhatian, dimana sebagian wilayah kabupaten belum dimanfaatkan secara optimal dalam upaya pengembagan usaha pertanian rakyat. Mengingat kondisi topografi Kabupaten Solok terdiri dari daerah perbukitan yang dialiri banyak sungai dengan topografi curam sampai sedang, maka daerah ini harus memperhatikan masalah konservasi lahan dan air, serta stabilitas kawasan dari kemungkinan terjadinya landslide dan kelongsoran serta aliran debris di musim hujan.

Dilihat dari sebaran lahan sawah di Kabupaten Solok, di bawah ini diberikan luas areal persawahan dan non-sawah menurut kecamatan.

Tabel 2. Luas Daerah Menurut Kecamatan

\begin{tabular}{|c|l|r|c|}
\hline \multirow{2}{*}{ No. Kecamatan } & \multicolumn{2}{|c|}{ Luas Lahan (Ha) } \\
\cline { 3 - 4 } & & Sawah & Non Sawah \\
\hline 1. & Pantai Cermin & 1.624 & 34.976 \\
2. & Lembah Gumanti & 2.048 & 43.924 \\
3. & Hiliran Gumanti & 1.442 & 24.886 \\
4. & Payung Sekaki & 1.252 & 35.198 \\
5. & Tigo Lurah & 1.200 & 59.050 \\
6. & Lembang Jaya & 2.466 & 7.524 \\
7. & Danau Kembar & 200 & 6.810 \\
8. & Gunung Talang & 3.366 & 35.134 \\
9. & Bukit Sundi & 3.050 & 7.850 \\
10. & IX Koto Sungai Lasi & 1.191 & 15.909 \\
11. & Kubung & 3.192 & 16.008 \\
12. & X Koto Singkarak & 2.012 & 27.538 \\
13. & Junjung Sirih & 692 & 9.558 \\
14. & X Koto Diatas & 1.378 & 24.322 \\
\hline & Kabupaten Solok & 25.113 & 348.687 \\
\hline
\end{tabular}

(Sumber : BPS Kabupaten Solok 2008)

\subsection{Sosial Kependudukan}

Lokasi studi berada pada Kenagarian Sirukan Kecamatan Bukit Sundi. Keberadaan daerah Irigasi Bandar Laweh yang direncanakan akan mengairi areal seluas $\pm 2000 \mathrm{Ha}$ akan sangat berpengaruh terhadap peningkatan produksi pertanian. Tetapi karena sebagian jaringan saluran tidak berfungsi, maka produksi yang diharapkan tidak dapat dicapai sesuai dengan rencana, dimana sebagian lahan persawahan menggunakan tadah hujan.

Di samping itu, masyarakat memanfaatkan aliran anak sungai yang terdapat pada lokasi yang dilalui jaringan irigasi, yaitu dari Lurah Kapecong pada daerah Irigasi Sirukam. Sedangkan sumber air yang semestinya untuk Lurah Kapecong adalah dari saluran sekunder kiri Bandar Laweh, yang salurannya ini melalui kecamatan Payung Sekaki dan Hiliran Gumanti. 
Tabel 3. Luas Daerah, jumlah dan kepadatan penduduk Menurut Kecamatan

\begin{tabular}{|c|c|c|c|c|}
\hline No. & Kecamatan & $\begin{array}{c}\text { Luas Daerah } \\
\left(\mathbf{k m}^{2}\right)\end{array}$ & Penduduk & $\begin{array}{c}\text { Kepadatan } \\
(\text { org/km²) }\end{array}$ \\
\hline 1. & Pantai Cermin & 366.00 & 20.298 & 55 \\
\hline 2. & Lembah Gumanti & 459.72 & 47.607 & 103 \\
\hline 3. & Hiliran Gumanti & 263.28 & 16.109 & 61 \\
\hline 4. & Payung Sekaki & 364.50 & 8.354 & 23 \\
\hline 5. & Tigo Lurah & 602.50 & 8.710 & 14 \\
\hline 6. & Lembang Jaya & 99.90 & 25.228 & 252 \\
\hline 7. & Danau Kembar & 70.10 & 19.199 & 274 \\
\hline 8. & Gunung Talang & 385.00 & 43.952 & 114 \\
\hline 9. & Bukit Sundi & 109.00 & 22.473 & 206 \\
\hline 10. & IX Koto Sungai Lasi & 171.00 & 10.179 & 59 \\
\hline 11. & Kubung & 192.00 & 53.498 & 279 \\
\hline 12. & X Koto Singkarak & 295.50 & 21.197 & 72 \\
\hline 13. & Junjung Sirih & 102.50 & 32.810 & 320 \\
\hline 14. & X Koto Diatas & 257.00 & 13.326 & 52 \\
\hline
\end{tabular}

(Sumber : BPS Kabupaten Solok 2008)

\subsection{Kondisi dan Kerusakan Saluran Irigasi}

Pemanfaatan sumber daya air Bandar Laweh yang utama saat ini adalah untuk irigasi pertanian yang alirannya sampai ke Nagari Tabek. Dengan tidak berfungsinya saluran dari Kenagarian Tabek menuju Lurah Kapecong, maka pasokan air irigasi untuk daerah Bukit Tandang sampai ke Solok hanya bersumber dari aliran anak sungai pada Lurah Kapecong. Tidak berfungsinya saluran primer kiri dan sebagian saluran primer kanan adalah akibat terjadinya kerusakan sepanjang saluran, mulai dari rusak ringan sampai berat seperti longsor. Pasokan air dimusim kemarau juga sangat terbatas, karena sumber air pada sungai juga terbatas dan rusaknya bangunan intake dan badan bendung.

\subsubsection{Kelongsoran pada Tebing Saluran}

Pada saluran garis tinggi seperti Gambar 1, terlihat bahwa kelongsoran tebing saluran menyebabkan tertimbunnya saluran, sehingga saluran akan meluap ke tanggul dan akan beresiko menimbulkan keruntuhan tanggul. Jika kelongsoran ini terjadi pada beberapa titik, misalnya dimusim hujan, maka cukup banyak titik-titik longsor yang akan terjadi pada tanggul saluran. Hal ini adalah salah satu kelemahan dari saluran garis tinggi apalagi berada pada tebing yang curam. Terutama di musim hujan, air yang akan mengalir pada saluran akan lebih besar bersumber dari aliran permukaan sehingga aliran air akan melimpah sepanjang saluran. Limpahan air ini akan merusak dan menggerus dasar tanggul bagian bawah dan dapat terjadi longsor pada badan saluran.
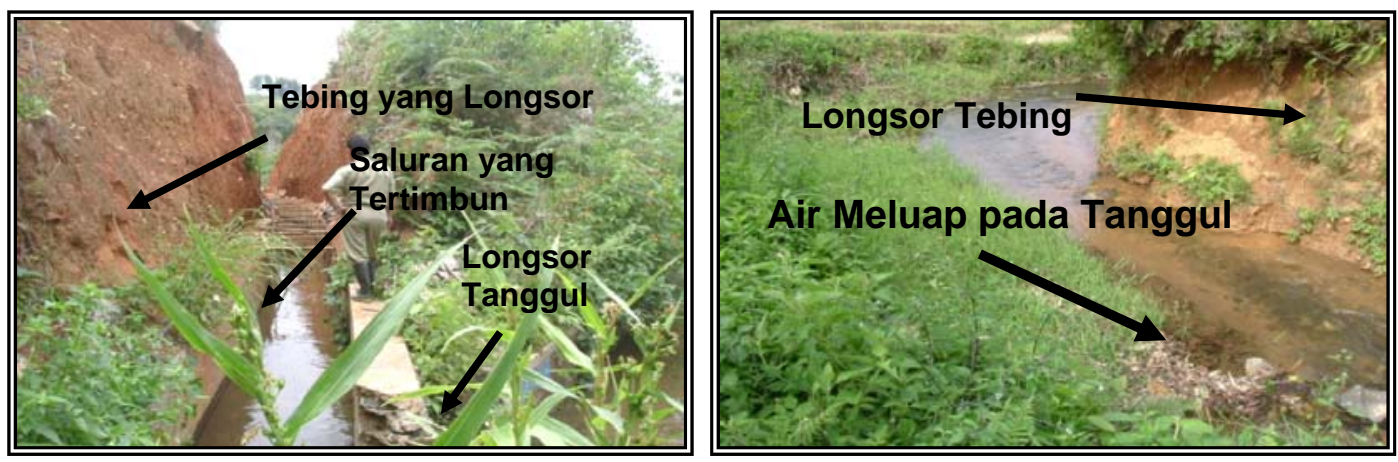

Gambar 1. Saluran Garis Tinggi Longsor Tebing dan Kerusakan Tanggul 


\subsubsection{Kebocoran Saluran}

Kebocoran tanggul saluran dapat diakibatkan oleh binatang atau hewan air seperti belut, dan juga karena kondisi tanah yang lolos air. Kebocoran yang pada mulanya kecil, lama kelamaan bisa menjadi bertambah besar karena butiran tanah disekitar bocoran akan selalu terbawa air. Di samping kebocoran pada satu titik, maka resapan air disekitar bocoran dapat pula memperlemah tanggul atau badan saluran yang berakibat longsornya saluran. Kelongsoran yang terjadi dapat dimulai dengan tanah gerak (landslide). Jika ini terjadi maka saluran akan semakin landai, aliran akan lebih lambat dan beban terhadap tanggul akan lebih besar sebagai pemicu terjadinya kelongsoran badan saluran. Gambar 2 di bawah menunjukkan kebocoran yang telah besar yang akan menggerus dasar tanggul dan dapat menimbulkan kelongsoran, walaupun saluran telah diperkuat dengan beton atau pasangan batu kali. Kebocoran semacam ini banyak ditemui sepanjang saluran primer kiri dan kanan Irigasi Bandar Laweh.
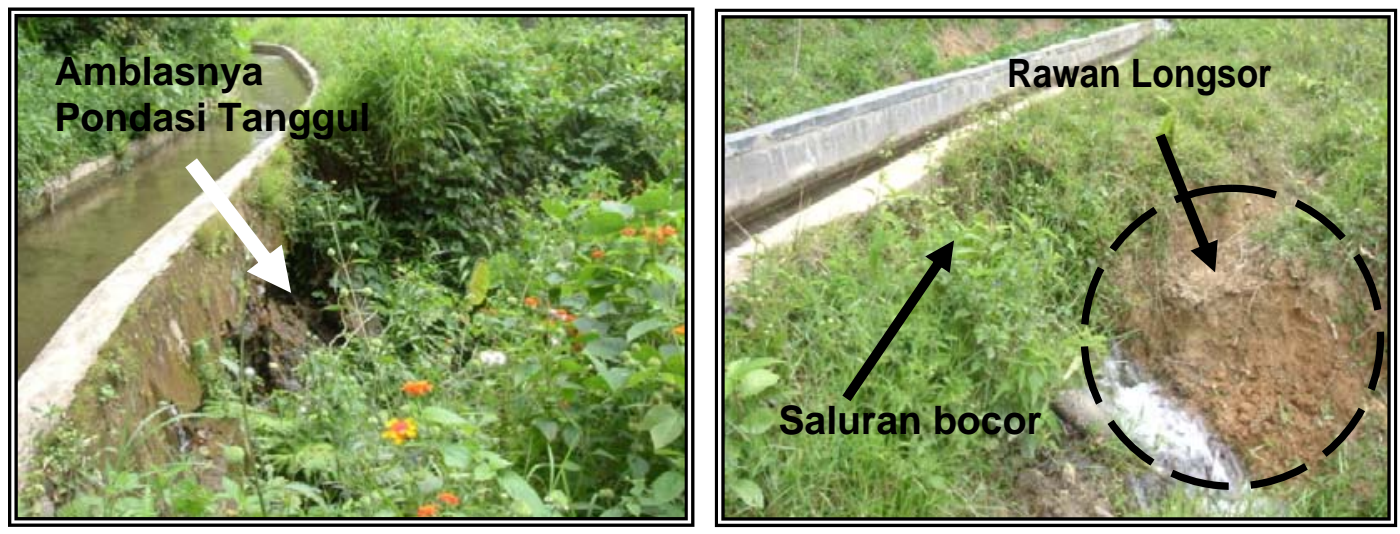

Gambar 2. Kebocoran Saluran Pondasi Amblas

\subsubsection{Kerusakan Pondasi Tanqqul}

Tanggul dengan pasangan batu kali yang di lining berada pada dudukan pondasi yang tidak kuat, sehingga tanggul tersebut tergantung dan sewaktu waktu dapat amblas. Kondisi ini terjadi karena pada beberapa titik yang dilalui saluran tidak ada pilihan lain trase walaupun berada pada dasar yang tidak stabil. Pertimbangan yang dilakukan selama ini adalah berdasarkan peta topografi dan sifat aliran pada saluran terbuka dengan kemiringan rencana tertentu. Seperti ditunjukkan pada Gambar 2, saluran berada pada tebing yang cukup curam. Pembuatan saluran dipaksakan walaupun dudukan pondasinya berada pada tanah yang tidak stabil (longsor atau landslide). Untuk menstabilkan lokasi semacam ini tentu dibutuhkan biaya yang tidak sedikit. Pergerakan tanah dasar ini akan semakin cepat jika musim hujan dan akan menambah tingkat kebocoran pada dasar saluran dimana terjadi rembesan air secara terus menerus.

\subsubsection{Longsor Pada Badan Saluran}

Kelongsoran pada badan saluran merupakan kerusakan berat yang membutuhkan penanganan khusus dan membutuhkan biaya yang besar. Keruntuhan yang berulang-ulang dapat saja terjadi karena lokasi yang bersangkutan tidak lagi stabil. Di samping itu, aliran air permukaan pada musim hujan juga mengalir ke lokasi ini. Dilihat dari lapangan, lokasi ini merupakan lahan yang mengalami landslide, sehingga penanggulangan yang kurang memperhatikan sifat-sifat tanah yang mengalami landslide akan sia-sia.

Pekerjaan yang dilakukan secara berulang-ulang pada lokasi yang sama dengan permasalahan yang sama merupakan cara yang sama sekali tidak profesional dan ini adalah kelemahan dari instansi 
pengelola selama ini. Penggunaan biaya yang besar dan tidak efektif akan memberikan citra yang buruk terhadap instansi pengelola.
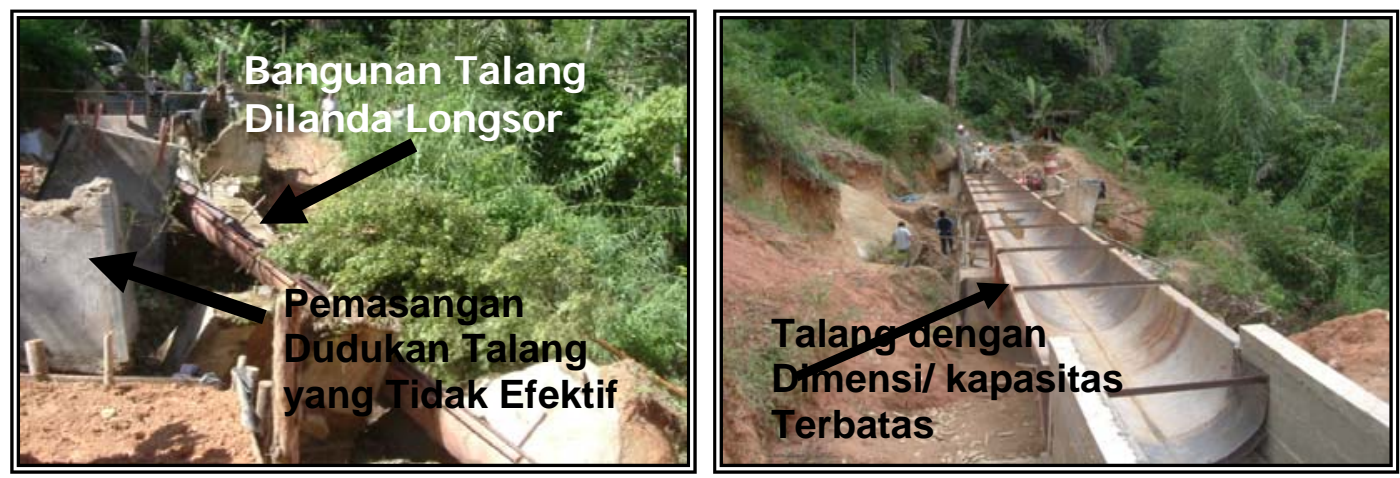

Gambar 3. Bangunan Talang yang Longsor

\subsection{Pembahasan}

Dari pemantauan bentuk ragam kerusakan pada saluran primer irigasi Bandar Laweh yang merupakan jenis saluran garis tinggi pada topografi yang curam, maka diperoleh beberapa catatan dalam hal kerusakan sepanjang saluran tersebut.

\subsubsection{Kelongsoran Tebing Saluran}

Kelemahan utama dari saluran garis tinggi adalah kelonsoran yang terjadi pada tebing saluran. Kelongsoran ini dapat terjadi karena jenis tanahnya yang lossed, kemiringan tebing yang curam, erosi serta jenuhnya air tanah akibat resapan yang terjadi mulai dari kemiringan bukit dimana saluran itu berada. Untuk menghindari kelongsoran pada tebing ini, dapat dilakukan upaya membuat terasering, penanaman rumput atau jenis lainnya yang dapat mengurangi pengikisan, serta perkuatan tebing dengan bangunan atau injeksi semen (soil cement). Perlakuan ini juga harus memperhatikan kelayakan dari segi teknis maupun ekonomis, karena dari pengamatan di lapangan pada beberapa lokasi, tebingnya curam sekali dan akan sulit untuk melakukan perbaikan trase saluran dan tebing serta tanggulnya.

Kelongsoran yang terjadi dan menimbun saluran akan berakibat kerusakan bagian yang lain seperti runtuhnya tanggul atau amblasnya badan saluran, sehingga kerusakan akan semakin meluas.

\subsubsection{Kebocoran Dasar dan Tangqul}

Kebocoran yang terjadi sepanjang saluran betapapun kecilnya akan menyebabkan kehilangan debit, sehingga kebutuhan air untuk persawahan tidak dapat terpenuhi. Pada saluran primer kiri dengan panjang saluran $18 \mathrm{~km}$, yang dialiri air hanya $4 \mathrm{~km}$ (pada daerah Tabek), sedangkan kebutuhan air untuk Bukit Tandang sampai Saok Laweh disuplai dari anak sungai Lurah Kapecong yang pada musim kemarau debit airnya kecil sekali. Praktis jaringan irigasi Bandar Laweh tidak berfungsi dengan baik. Penanganan teknis kerusakan saluran irigasi yang dilakukan hanya dapat memecahkan permasalahan aliran pada saluran untuk jarak tertentu dan tidak dapat mencapai areal persawahan yang lebih hilir.

Disamping kehilangan air, kebocoran dan resapan air sepanjang tanggul dan dasar saluran juga dapat menimbulkan kelongsoran atau amblasnya saluran. Biasanya kebocoran yang terjadi menunjukkan peningkatan jumlah dan besarnya, serta posisi yang sering berpindah-pindah. Jadi disini permasalahan kebocoran pada saluran mengurangi pemasokan air untuk irigasi dan rusaknya badan saluran. 


\subsubsection{Amblasnya Badan Saluran}

Kerusakan berat yang terjadi adalah kelongsoran pada badan saluran. Keruskan semacam ini akan sangat berpengaruh terhadap irigasi, karena akan terhentinya aliran untuk irigasi pada saat rehabilitasi. Penanganan masalah kelongsoran tidak ditangani dengan baik, terutama teknik penanggulangi yang tidak memperhitungkan kondisi stabilitas lereng (pada lahan yang mengalami landslide). Dudukan pondasi bangunan talang yang dibangun pada daerah yang longsor tidak dipehitungkan terhadap kestabilannya, karena berada pada dasar yang labil (tanah gerak). Di samping itu pemicu kelongsoran yang bersumber dari aliran air tebing dan meluapnya debit aliran pada saluran tidak ditanggulangi dengan baik. Penanganan yang dilakukan bersifat parsial, tanpa kajian teknis dan analisis yang mendalam, sehingga perbaikan yang dilakukan sering mengalami kegagalan.

\subsubsection{Alternatif Pemecahan Masalah}

Setelah mempelajari berbagai permasalahan pada saluran primer irigasi Bandar Laweh yang merupakan saluran garis tinggi, maka upaya penanggulangan yang bersifat komprehensif harus dilakukan, diantaranya :

1. Melakukan perhitungan ulang terhadap kebutuhan air irigasi areal persawahan, dimana sebagian areal ini mempunyai jarak yang cukup jauh dari intake.

2. Memperhitungkan dengan teliti kehilangan air sepanjang saluran, sehingga dapat diketahui debit yang diperlukan dari intake, agar kebutuhan air irigasi dapat dipenuhi. Dengan mengetahui debit intake, maka dimensi saluran dapat dirancang sedemikian dapat mengalirkan air dengan debit yang dapat memenuhi kebutuhan irigasi sampai pada lokasi persawahan yang direncanakan.

3. Diperlukan perencanaan ulang, yang meliputi survei topografi, penyelidikan tanah (jenis tanah, stabilitas lereng dan landslide), debit air permukaan pada lereng bukit dimana direncanakan trase saluran, serta aliran-aliran yang terjadi pada daerah lereng bukit.

4. Memilih tipe saluran pada trase yang direncanakan, saluran tertutup, talang, saluran terbuka. Pada topografi yang curam, dipilih saluran tertutup (pipa), pada daerah landslide dipilih saluran tertutup elastis (pipa karet) dengan dudukan yang dapat dimodifikasi setiap adanya penurunan permukaan tanah. Pada daerah yang relatif stabil dapat direncanakan saluran terbuka.

5. Membuat bangunan kontrol pada posisi-posisi penambahan debit akibat aliran permukaan pada lahan, agar debit aliran yang melewati saluran tidak meluap sehingga tidak terjadi kelongsoran. Pada bangunan kontrol ini dapat dilengkapi dengan bangunan peluap.

\section{PENUTUP}

\subsection{Kesimpulan}

Dari studi yang dilakukan, dapat diambil beberapa kesimpulan sebagai berikut :

1 Saluran garis tinggi pada topografi yang curam akan mengalami banyak masalah, seperti kebocoran saluran, kelongsoran tebing, tanggul dan badan saluran itu sendiri.

2 Kebocoran sepanjang saluran menyebabkan suplai air untuk irigasi tidak dapat terpenuhi, malahan saluran yang bagian ujung mengalami kekeringan (tidak berfungsi lagi).

3 Dimensi saluran harus direncanakan untuk dapat mengalirkan air dengan debit intake yang memperhitungan kehilangan debit sepanjang saluran.

4 Pemilihan jenis dan dimensi saluran harus disesuaikan dengan kondisi topografi dan geologi lapangan agar dapat meminimumkan biaya operasi dan pemeliharaan. 


\subsection{Saran}

Untuk mengantisipasi permasalahan pada jaringan irigasi Bandar Laweh, sebaiknya dilakukan beberapa hal di bawah ini :

1. Perencanaan ulang jaringan irigasi dengan melakukan kajian yang menyeluruh tentang kondisi topografi, geologi, sosial ekonomi dan SDM dalam operasional dan pemeliharaan.

2. Rehabilitasi yang dilaksanakan selama ini tidak banyak memberikan hasil, karena terbatasnya dimensi saluran sehingga suplai air tidak dapat mencapa semua areal irigasi yang direncanakan.

\section{DAFTAR PUSTAKA}

Departemen Pemukiman dan Prasarana Wilayah Direktorat Jenderal Sumber Daya Air, (2001), ”Studi Lingkungan Pengelolaan Sumber Daya Air”, Final Report Anai - Kandis River Basin and Resources Management, Oktober 2001.

Dinas Pengelolaan Sumber Daya Air, Propinsi Sumatera Barat, (2001), "Studi Tata Guna Air Batang Suliti - Bangko Kabupaten Solok".

Maksum Hidayat, (1997), ”Tata Cara Perhitungan Ketersediaan Air Irigasi”, Direktorat Jenderal Pengairan, Proyek Pendidikan dan Peningkatan Pengairan, Bandung.

Direktorat Jenderal Pengairan, Departemen Pekerjaan Umum, (1986), "Standar Perencanaan Irigasi, Kriteria Perencanaan (KP) 01”, C.V. Galang Persada, Bandung.

Suyono Sosrodarsono, Takeda Kensaku, (1985), "Hidrologi untuk Pengairan”, P.T. Pradnya Paramita, Jakarta. 
Jenis dan Ragam Kerusakan Saluran Primer Daerah Irigasi Bandar Laweh Kabupaten Solok

\section{6 | JURNAL REKAYASA SIPIL}

